\title{
Pembahasan Hasil Penelitian \\ PENERAPAN STRATEGI PEMBELAJARAN KOSAKATA \\ PEMBAHASAN HASIL PENELITIAN “UPAYA PENINGKATAN INTERAKSI \\ DAN AKTIVITAS BELAJAR DALAM PEMBELAJARAN KOSAKATA DENGAN STRATEGI ANALISIS FITUR SEMANTIK"
}

\author{
Kastam Syamsi \\ FBS Universitas Negeri Yogyakarta
}

\section{A. Pendahuluan}

Penguasaan kosakata merupakan salah satu aspek penguasaupakan salah satu aspek penguasaualitas keterampilan berbahasa seseorang bergantung pada kuantitas dan kualitas kosakata yang dimiliki (Tarigan, 1984). Dengan kata lain, semakin kaya kosakata yang dimiliki seseorang, semakin terampilah orang itu dalam berbahasa.

Mengingat begitu pentingnya penguasaan kosakata itu, sudah semestinya pembelajaran bahasa juga memperhatikan bagaimana menerapkan strategi pembelajaran kosakata yang tepat di berbagai jenjang dan jenis pendidikan. Namun demikian, kenyatan di lapangan menunjukkan bahwa terdapat kekurangan penguasaan guru atas berbagai model dan strategi pembelajaran tersebut. Dalam hal ini, tema yang diangkat dalam penelitian Saudara Ari Kusimiatun menemukan kebermanfaatannya.

Biasanya, memang, dalam pembelajaran kosakata di sekolah guru mengikuti apa yang sudah disiapkan dalam buku teks pelajaran bahasa. Aktivitas dan atau strategi yang biasanya dilakukan meliputi pencarian sinonim dan antonim, pencairan makna kata dalam kamus, penyusunan kalimat dengan kosakata yang baru dipelajari, atau bahkan hanya berupa penghapalan sejumlah kosakata baru.

Penulis sependapat bahwa di lapangan, pembelajaran kosakata cenderung membosankan siswa. Siswa, memang, hanya ditempatkan sebagai pendengar dan pencatat saja, hampir-hampir tidak ada partisipasi siswa secara aktif. Barangkali, ini disebabkan peran guru, yang disebut peneliti sebagai "kamus berjalan". Gurulah yang menjadi sumber informasi tentang seluk-beluk kosakata. Untuk mengatasi permasalahan itu, Guru semestinya senantiasa meningkatkan kompetensinya dalam kegiatan pembelajaran.

Tulisan ini bertujuan untuk membahas hasil penelitian terhadap penerapan strategi Analisis Fitur Semantik yang dilakukan oleh Ari Kusmiatun dengan judul Upaya Peningkatan Interaksi dan Aktivitas Belajar dalam Pembelajaran Kosakata dengan Strategi Analisis Fitur Semantik. Pembahasan terutama difokuskan pada teori dan metode yang dipakai peneliti untuk memecahkan masalah penelitian.

\section{B. Pembahasan}

Dalam penelitiannya, Kusmiatun mencoba untuk memecahkan permasalahan akan lemahnya posisi siswa dalam pembelajaran kosakata dan dominannya posisi guru dalam pembelajaran kosakata dengan menerapkan strategi Analisis Fitur Semantik. Penelitian tersebut bertujuan untuk (1) memperbaiki proses pembelajaran bahasa dan sastra Indonesia, khususnya pembelajaran kosakata, yang dapat me- 
narik siswa untuk aktif dan interaktif dalam pembelajaran di kelas, dan (2) meningkatkan kemampuan siswa dalam penguasaan kosakata.

Pembelajaran kosakata memang berbeda dengan pemerolehan kosakata. Dalam teori pemerolehan kosakata antara lain disebutkan bahwa peristiwa real pertama seorang anak mengembangkan bahasanya terjadi ketika is menuturkan kata pertama (Tomkins \& Hoskisson, 1995). Peristiwa ini dapat terjadi sesudah atau sebelum anak itu merayakan ulang tahun pertamanya (Graves, 1987). Kemudian, pada usia kurang lebih 3 bulan setelah memunculkan kata pertamanya, anak itu mungkin sudah mempelajari tambahan 50 kata baru. Selama periode ini, anak-anak berbicara secara khusus dengan satu tuturan kata. Setelah mengumpulkan 50 kata atau lebih, anak-anak itu mulai merangkai kosakata bersamasama untuk membentuk kalimat, pertama kalimat dua kata, kemudian kalimat 3 kata, dan terus bertambah.

Pemerolehan kosakata selanjutnya mengikuti pola-pola yang umum terjadi pada semua anak. Imitasi dan penguatan, serta belajar perbedaan merupakan komponen dalam pola-pola ini (Petty, Herold, \& Stool, 1968). Tomkins Hokisson (1995) menambahkan bahwa karena belajar bahasa bersifat alamiah dan sosial, seorang anak belajar berbicara melalui imersi dan interaksi dengan keluarga yang lain serta lingkungan masyarakat sekitar mempunyai peranan yang penting dalam pemerolehan kosakata seorang anak. Selama usia prasekolah, orang tua memainkan peranan (kontribusi) yang penting dalam perkembangan bahasa anak dengan menyediakan kesempatan anak (Tomkins \& Hokisson, 1995). Menurut Nagy \& Herman (1987) untuk sebagian anak-anak, cara berbicara orang tua dengan teman sebaya mungkin merupakan sumber yang san- gat signifikan terhadap pertambahan kosakata anak.

Ketika seorang anak masuk ke sekolah, ia telah memiliki sejumlah kosakata fungsional (Petty, Herold, \& Stoll, 1968). la telah memahami sejumlah besar kosakata, meskipun mereka tidak dapat menggunakannya dalam berbicara. Pada masa ini, perkembangan kosakata anak merupakan sesuatu yang sangat mengesankan (Graves, 1987). Orang tua kadang-kadang merasa terkejut dan heran atas perkembangan perbendaharaan kosakata anak-anak mereka. Anak-anak telah mempelajari sejumlah kosakata yang penting, dan untuk sebagian besar anak-anak, pengajaran langsung memainkan peran yang penting dalam pemerolehan kosakata tersebut. Salah satu tugas penting bagi guru-guru terutama pada tingkat pendidikan prasekolah dan pendidikan dasar adalah untuk meningkatkan pemahaman anak-anak terhadap kosakata umum, bukannya untuk hanya memberikan sejumlah kosakata baru (Petty, Herold, \& Stoll, 1968).

Penguasaan kosa kata sebagaimana terlihat melalui pemahaman terhadap kata dan penguasaan konsepnya tidak selalu sama (Petty, Herold, \& Stoll, 1968). Seorang anak yang masih sangat muda khususnya memiliki pengetahuan konseptual, tetapi tidak dapat mendiskripsikannya dengan kosakata atau menghubungkan pada kosakata dengan ingatan.

Makna kata memiliki hubungan sangat dekat dengan konsep (Petty, Herold, \& Stoll, 1968). Kata round, sebagai contoh, membawa suatu konsep tentang roundness (kebulatan) pada para pembaca atau pendengarnya karena pemahaman mereka baik dengan konsep maupun dengan kosaktanya. Makna roun dapat diajarkan pada para pemegang. Konsep roundness jika pengajaran kata itu dapat menjadi asosiasi simbol 
dengan referen yang khusus. Makna kata juga didasarkan pada konteks, atau kosakata yang melingkupinya (Tomkins \& Hokisson, 1995). Anak-anak siswa SD pada umumnya belum memiliki seluruh makna kata seperti yang dimiliki orang dewasa, lebih tepatnya, mereka belajar makna melalui suatu proses perbaikan.

Makna kata dipelajari dalam situasi yang berbeda-beda, dalam tingkat kelengkapan yang berbeda, dan dalam kalimat keberhasilan yang berbeda pula (Elhout-Mohr \& van Daalen-Kapteijn, 1987). Proses belajar makna kta mulai sejak awal kehidupan seorang anak sampai ia dewasa. Ini dapat dikatakan bahwa seseorang akan terus menambah kosakata selama kehidupannya. Menurut Elhout-Mohr \& van DaalenKapteijn (1987) ada tiga faktor yang mempengaruhi pembelajaran makna yakni (1) frekuensi penggunaan kata atau frekuensi penggunaan kosakata terhadap pembelajar, (2) keanekaragaman situasi atau konteks penggunaan kosakata, dan (3) penampilan standar yang diadakan. Menurut hasil eksperimen, mereka juga menyimpulkan bahwa ada tiga komponen dalam proses pemerolehan makna kata, yakni (1) penggunaan model, (2) proses dekontekstualisasi, dan (3) pengelompokan unit makna kata. Selain itu, ada empat proses terpisah perkembangan makna kata, yakni (1) perluasan kosakata melalui penambahan kata baru dengan harapan hanya penambahan kecil terhadap makna, (2) pemerolehan makna baru dari makna lama dengan mempelajari perbedaan, (3) melaksanakan pengalaman-pengalaman baru yang menghasilkan makna baru, dan (4) belajar kosakata secara insidental ketika berdiskusi dan membaca (Petty, Herold, \& Stoll, 1968).

Dalam studi yang dilakukan oleh Terman tahun 916 dan Wechsler tahun 1949 (Chall, 1987), disimpulkan bahwa penguasaan makna kata mempunyai korelasi yang tinggi dengan intelegensi verbal. Selain itu, penguasaan makna kata juga merupakan faktor yang sangat kuat pengaruhnya terhadap membaca pemahaman. Peneliti tentang keterbacaanpun, seperti yang dinyatakan Chall mendukung hal itu. Ia menyimpulkan bahwa tingkat kesulitan kosakata mempunyai korelasi yang tinggi dengan tingkat kesulitan pemahaman, lebih tinggi dari faktor sintaksis atau struktur lain. Pada dasarnya, penelitian mutakhir juga meyakinkan hasil penelitian terdahulu bahwa penguasaan makna kata adalah faktor penting dalam perkembangan membaca pemahaman dan dalam menilai keterbacaan teks; bahwa makna kata dapat diajarkan secara langsung, terutama untuk siswa yang memiliki kemampuan rendah, dan bahwa makna kata juga dipelajari melalui konteks dalam membacan (Chall, 1987).

Kosakata diperoleh melalui pengalaman dan hubungan pengalaman dengan kata (Petty, Herold, \& Stoll, 1968). Semakin banyak pengalaman yang diperoleh, semakin banyak pula kosakata yang dikuasai. Selain itu, pemerolehan kosakata adalah proses manusiawi yang tergantung pada tingkatan intelegensi dan lingkungan, suatu proses yng tidak dapat ditolak dalam kondisi normal kehidupan seorang manusia (Petty, Herold, \& Stoll, 1968). Ini berarti, seperti sudah dinyatakan sebelumnya, fak tor keturunan dan lingkungan sangat berpengaruh terhadap pemerolehan kosakata seseorang.

Sementaraitu, pembelajaran kosakata di sekolah-sekolah pada umumnya dilakukan melalui (1) pengajaran kosakata dan maknanya melalui penggunaannya dalam konteks, (2) suatu proses analisis dan sintesis terhadap kosakata ketika elemen makna kata diajarkan, (3) pengajaran langsung terhadap makna kata 
dari daftar kata (Petty, Herold, \& Stoll, 1968). Menurut Klesius \& Searls (1991) pengajaran kosakata meliputi pengajaran tak langsung untuk meningkatkan kosakata umum dan pengajaran langsung terhadap kosakata khusus untuk topik tertentu atau wacana yang akan dibaca. Beck \& McKeown (1991) juga mempertimbangkan berbagai sumber yang harus mendapat perhatian dalam penelitian kosakata selama pelajaran di sekolah, yakni konteks tertulis dan pengajaran langsung di kelas.

Dalam hal pembelajaran kosakata ini, peneliti telah berupaya menerapkan apa yang disebut Klesius \& Searsls (1991) di atas sebagai metode langsung. Peneliti memfokuskan kajian pembelajaran pada sejumlah kosakata yang terdapat dalam wacana dengan menerapkan strategi Analisis Fitur Semantik.

Pada umumnya, pembelajaran kosakata diarahkan dalam rangka peningkatan penguasaan kosakata untuk berbagai jenis dan keperluan, baik lisan maupun tertulis, dan baik kosakata reseptif maupun produktif. Sesuai dengan strategi yang dipilih, peneliti bermaksud menerapkan strategi Analisis Fitur Semantik untuk meningkatkan interaksi belajarmengajar dan penguasaan kosakata. Namun, karena terlalu asyik membahas efek interaksi, tampaknya bagaimana proses peningkatan penguasaan kosakata hanya disajikan sepintas. Tidak ada informasi yang menjabarkan bagaimana proses peningkatan kuantitas dan kualitas penguasaan kosajata yang diperoleh siswa.

Selain itu, pemilihan strategi Analisis Fitur Semantik belum tentu cocok diterapkan. Ini dikarenakan strategi tersebut sesungguhnya hanya cocok diterapkan pada pengenalan kosakata baru (Patrick, 1996). Padahal untuk anakanak seusia SMK, tempat penelitian dilakukan, hampir jarang sekali ditemu- kan kosakata baru. Bagi para siswa, kosakata Bahasa Indonesia yang sudah mereka miliki sesungguhnya sudah sangat cukup dikuasai melalui proses pemerolehan. Kenyataan menunjukkan bahwa bagi anak-anak Indonesia, apalagi yang lahir setelah tahun 1980-an dengan menjamurnya media massa, mereka sejak kecil telah dipertemukan dengan minimal dua bahasa sekaligus, yakni bahasa ibu dan bahasa Indonesia.

Dilihat dari konteksnya, saat penelitian berlangsung, peneliti berperan sebagai guru mata pelajaran Bahasa Indonesia di SMK. Untuk itu, pemilihan jenis penelitian, yakni Penelitian Tindakan Kelas (PTK), sangat tepat diterapkan. PTK memang sangat tepat dilaksanakan oleh guru-guru di kelas untuk memecahkan berbagai permasalahan mereka sendiri.

Namun demikian, subjek penelitian tidak disebutkan dengan jelas bagaimana jumlah dan karakteristiknya. Akan sangat bermanfaat bagi pembaca, jika subjek penelitian dideskripsikan dengan lengkap. Sementara itu, pemilihan teknik pengumulan data sudah cukup tepat diuraikan. Bahkan, validitas dan reliabilitas data pun disajikan. Akan tetapi, tidak ada informasi tentang validitas penelitian apa yang dipilih oleh peneliti. Dalam penelitian PTK, menurut Burns (1999: 161-162) validitas yang digunakan bisa berupa validitas demokratik, validitas proses, dan validitas dialogik. Oleh karena itu, akan lebih sempurna jika di dalam artikel hasil penelitian tersebut juga disajikan validitas apa yang dipilih.

\section{Penutup}

Demikianlah beberapa catatan penulis. Memang tak ada gading yang tak retak. Yang jelas, apa yang sudah dilakukan peneliti, merupakan salah satu upaya yang harus disambut hangat di tengah-tengah monotonnya model pem- 
belajaran dan miskinnya guru terhadap berbagai macam penerapan strategi pembelajaran, khususnya pembelajaran kosakata.

\section{Daftar Pustaka}

Beck, I., \& McKeown, M.G. 1991. "Condition of Vocabulary Acquisition", dalam P. D. Pearson, R. Barr, M.L. Kamil, \& P. Mosenthal (Eds.), Handbook of Reading Research, Vol. II, (hal. 780-814). White Plains, NY: Longman.

Blachowich, C. \& Peter, F. 1996. Teaching Vocabulary in all Classroom. Englewood Cliffs: Prentice-Hall, Ltd.

Burns, A. 1999. Coollaborative Action Research for English Language Teachers. Cambridge: Cambridge University Press.

Chall, J.S. 1987. "Two Vocabularies for Reading: Recognition and Meaning", dalam McKeown \& M.E. Curtis (Eds.), The Nature of Vocabulary Acquisition, (hal. 118). Hiledale, NJ: Earlbaum.

Elshoue-Mohr, M., \& van DaalenKapteijns. 1987. “Cognitive Processes in Learning Word Meaning", dalam McKeown \& M.E. Curtis (Eds.), The Nature of Vocabulary Acquisition, (Hal. 5371). Hiledale, NJ: Earlbaum.
Graves, J.P. 1987. “The Role of Instruction in Fostering Vocabulary Development", dalam McKeown \& M.E. Curtis (Eds.), The Nature of Vocabulary Acquisition, (Hal. 165-184). Hiledale, NJ: Earlbaum.

Patrick, J.F. 1996. Helping Children Learn to Read. New York: Random House.

Klesius, J., \& Searls, E. 1991. “Vocabulary Instruction", dalam Reading Psychology, 12, 165-171.

McKeown, M.G., \& Curtis, M.E. (Eds.). 1987. The Nature of Vocabulary Acquisition. Hiledale, NJ: Earlbaum.

Nagy, W.E. \& Herman, P. 1987. "Breadth and Depth of Vocabulary Knowledge: Implication for Acquistion and Instruction", dalam McKeown \& M.E. Curtis (Eds.), The Nature of Vocabulary Acquisition, (Hal. 19-35). Hiledale, NJ: Earlbaum.

Petty, W. T., Herold, C.P. and Stoll, E. 1968. The State of Knowledge about the Teaching Vocabulary. Champain, IL: National Council of Teachers of English.

Tarigan, H. G. 1984. Pengajaran Kosakata. Bandung: Angkasa.

Tompkins, G. E. , \& Hoskisson, K. 1995. Language Arts: Content and Teaching Strategies. Thrid Edition. Englewood Cliffs, NJ: Merril. 